\title{
Pesan dari Editor-in-Chief: Tantangan Psikologi Siber
}

\author{
Bagus Takwin \\ Fakultas Psikologi, Universitas Indonesia, Depok
}

Penelitian psikologi tentang tingkah laku di dunia siber (cyber), termasuk di situs jejaring sosial (seperti Facebook dan Instagram yang popularitasnya sangat tinggi), masih sedikit-apalagi di Indonesia. Begitu pun penelitian terkait fenomena tersebut di bidang psikologi sosial juga masih kurang. Padahal, banyak isu penting yang perlu dikaji di dunia siber, seperti bagaimana tingkah laku orang berubah di dunia daring (online), mengapa orang bertingkah laku berbeda ketika berada di dunia maya, mengapa mereka bertingkah laku seperti yang mereka tampilkan di internet dan media sosial, perilaku jual-beli daring, kecanduan di dunia maya, keadaan orang menghadapi risiko pengungkapan intim secara daring, hubungan intim dan persahabatan daring, hubungan antara individu dan institusi, bagaimana orang membina jejaring di dunia maya, kejahatan siber, sikap dan kecenderungan lainnya dalam menjaga data dan kerahasiaan pribadi serta antisipasi terhadap bocornya rahasia pribadi, juga pengawasan pemerintah yang semakin mengikis kepercayaan akan integritas dan privasi komunikasi daring.

Dunia siber, atau dunia maya, mengacu pada lingkungan daring tempat banyak individu terlibat dalam interaksi sosial dan memiliki kemampuan untuk saling menggugah dan mempengaruhi. Belakangan himpunan kajian fenomena itu disebut Psikologi Siber (cyberpsychology), yang didefinisikan sebagai studi tentang pikiran manusia dan tingkah lakunya dalam konteks interaksi manusia serta komunikasi manusia dan mesin. Batas psikologi siber kini semakin meluas seiring dengan berkembangnya budaya komputer dan realitas virtual yang berlangsung di internet.

Dewasa ini, internet digunakan secara luas di kehidupan masyarakat. Populasi manusia di dunia maya sangatlah besar. Pada 2020, diperkirakan akan ada hampir 4,1 miliar pengguna internet. Artinya sejumlah orang menggunakan internet untuk berbagai kepentingan, seperti memecahkan masalah, menghasilkan uang, berinteraksi dengan orang lain, berpolitik, mencari hiburan, juga menyerang dan menjelekkan orang lain. Dunia siber menjadi ajang dan wahana aktivitas banyak sekali manusia. Dengan kondisi demikian, psikologi siber akan memainkan peran kunci dalam memahami tingkah laku dan tindakan orang-orang di ruang siber. Kini di banyak negara, bandwidth yang besar sudah dapat diakses oleh para pengguna internet, dengan rata-rata bandwidth lalu lintas 44,1 GB per bulan. Kondisi itu mendorong manusia untuk menciptakan dunia virtual yang sama sekali baru untuk bertingkah laku dan berinteraksi. Untuk dapat memahami dan menjelaskannya diperlukan banyak penelitian.

Psikologi siber merupakan sub-bidang psikologi yang berkaitan dengan efek psikologis serta implikasi komputer dan teknologi daring seperti internet dan realitas virtual. Ruang lingkupnya mencakup juga tingkah laku di media sosial, kecanduan internet, masalah dengan situs kencan daring, cyberbullying, dan aspek-aspek lain tentang bagaimana orang berperilaku daring. Di dalamnya tercakup juga penelitian terhadap interaksi manusia-komputer, atau penyajian psikoterapi daring. Psikologi siber sudah dimulai pada pertengahan 1990-an (Suler, 1996-2007; Whittle, 1997; Wallace, 1998; Gordo-López \& Parker, 1999), tetapi bisa dibilang baru mulai mencuat pada dekade terakhir ini.

Belakangan ini, meski belum banyak dibandingkan bidang psikologi terdahulu, hasil penelitian psikologi siber menawarkan wawasan untuk memperbaiki gaya hidup dan meningkatkan kesejahteraan di era digital. Prinsip-prinsip dasarnya dapat digunakan untuk penelitian berbagai topik, termasuk manajemen identitas daring, disinhibisi, komunikasi melalui teks dan foto, keintiman dan kesalahpahaman dalam hubungan daring, sikap yang saling bertentangan terhadap media sosial, kecanduan, perilaku menyimpang, realitas virtual, kecerdasan buatan, serta overload media (Suler, 2015). Sudah ada kerangka kerja yang dapat digunakan dalam meneliti fenomena dunia siber, seperti yang dikemukakan Suler (2015), yaitu 'Delapan Dimensi Arsitektur Psikologi Siber' ('Eight Dimensions of Cyberpsychology Architecture') yang dapat diterapkan oleh para peneliti dan mahasiswa sebagai alat yang berharga untuk membuat dan memahami berbagai fenomena dunia digital. Psikologi siber bisa disebut juga sebagai "Psikologi Zaman Digital" yang berfokus pada manusia sebagai individu dengan berbagai sepak-terjangnya di dunia siber. Kerangka kerja itu dapat memberikan cahaya baru pada reaksi sadar dan juga bawah-sadar kita terhadap pengalaman daring dan kebutuhan intrinsik manusia untuk mengaktualisasikan diri.

Kini, dunia telah sangat berubah dalam banyak cara bagi banyak orang. Itu terutama disebabkan oleh institusi sosial dan individu telah 
menyaksikan dan berpartisipasi dalam revolusi sosial lain: revolusi teknologi informasi melalui internet. Bukan saja ketersediaan dan aksesibilitas informasi dalam segala jenis dan inovasi dramatis dalam komunikasi antarpribadi, melainkan juga ketersediaan ruang dan masyarakat baru yang memungkinkan munculnya berbagai interaksi baru dan aktivitas baru lainnya, bahkan tatanan sosial baru.

Banyak orang dan perusahaan di seluruh dunia mengakui bahwa dengan menggunakan internet secara optimal, mereka mengalami peningkatan signifikan dalam beragam kegiatan pribadi dan bisnis, baik itu di bidang pekerjaan, sosial, bisnis, maupun yang terkait dengan pemerintah. Kita bisa saksikan juga banyak orang dan perusahaan yang ikut dalam "perlombaan kompetitif" di bisnis teknologi informasi dan internet, disertai dengan kreativitas dan potensi tinggi. Mereka berkembang maju dan memperkuat penggunaan komputer yang lebih intensif dalam berbagai kegiatan. Perkembangan teknologi yang luar biasa telah mengubah tatanan dunia orang dan kehidupan dalam banyak cara, mulai dari mencari dan menggunakan informasi tentang topik apa pun hingga ke banyak aktivitas di ranah lain. Kita saksikan sekarang sudah umum internet digunakan untuk kegiatan belanja dan perdagangan, komunikasi dengan kenalan dan orang asing, kencan virtual dan membina kehidupan cinta, belajar dan mengajar, penelitian, membantu dan dibantu orang lain, meningkatkan penggunaan obat-obatan dan aspek perawatan kesehatan lainnya, memperoleh hiburan dan rekreasi, serta ekspresi diri.

Dunia siber kini merupakan tatanan masyarakat tersendiri dengan segala aktivitas manusia-manusianya. Sekali lagi, untuk dapat memahami dan menjelaskannya diperlukan kajian dan penelian baru. Ini adalah tantangan bagi para peneliti psikologi sosial di Indonesia untuk melakukan penelitian terhadap fenomena itu. Lahan yang masih belum banyak digarap menanti mereka agar menghasilkan pemikiran dan penjelasan terbaik untuk dibagikan ke seluruh dunia.

\section{Referensi}

Gordo-López, J. \& Parker, I. (1999). Cyberpsychology. New York: Routledge.

Suler, J. (1996-2007). The psychology of cyberspace. Retrieved Februari 2, 2020, from http://www.rider.edu/ suler/psycyber/psy cyber.html

Suler, J. (2015). Psychology of the Digital Age; Humans Become Electric. Cambridge: Cambridge University Press.

Wallace, P. M. (1998). The Psychology of the Internet. Cambridge: Cambridge University Press.

Whittle, D. B. (1997). Cyberspace: The human dimension. New York: W.H. Freeman. 